\title{
Biocontrol of larval mosquitoes by Acilius sulcatus (Coleoptera:
} Dytiscidae)

\author{
Goutam Chandra*, Samir K Mandal, Arup K Ghosh, Dipanwita Das, \\ Siddhartha S Banerjee and Sumanta Chakraborty
}

Address: Mosquito Research Unit, Department of Zoology, the University of Burdwan, West Bengal, India

Email: Goutam Chandra* - goutamchandra63@yahoo.co.in; Samir K Mandal - indra_c2006@yahoo.co.in; Arup K Ghosh - indra_c2007@yahoo.co.in; Dipanwita Das - dipa8das@rediffmail.com;

Siddhartha S Banerjee - siddhartha_c2007@yahoo.co.in; Sumanta Chakraborty - banerjee.sidh@gmail.com

* Corresponding author

Published: 15 October 2008

BMC Infectious Diseases 2008, 8:138 doi:10.1/86/147/-2334-8-138

This article is available from: http://www.biomedcentral.com/I47I-2334/8//38

(c) 2008 Chandra et al; licensee BioMed Central Ltd.

This is an Open Access article distributed under the terms of the Creative Commons Attribution License (http://creativecommons.org/licenses/by/2.0), which permits unrestricted use, distribution, and reproduction in any medium, provided the original work is properly cited.
Received: 30 May 2008

Accepted: 15 October 2008

\begin{abstract}
Background: Problems associated with resistant mosquitoes and the effects on non-target species by chemicals, evoke a reason to find alternative methods to control mosquitoes, like the use of natural predators. In this regard, aquatic coleopterans have been explored less compared to other insect predators. In the present study, an evaluation of the role of the larvae of Acilius sulcatus Linnaeus 1758 (Coleoptera: Dytiscidae) as predator of mosquito immatures was made in the laboratory. Its efficacy under field condition was also determined to emphasize its potential as biocontrol agent of mosquitoes.
\end{abstract}

Methods: In the laboratory, the predation potential of the larvae of $A$. sulcatus was assessed using the larvae of Culex quinquefasciatus Say 1823 (Diptera: Culicidae) as prey at varying predator and prey densities and available space. Under field conditions, the effectiveness of the larvae of $A$. sulcatus was evaluated through augmentative release in ten cemented tanks hosting immatures of different mosquito species at varying density. The dip density changes in the mosquito immatures were used as indicator for the effectiveness of $A$. sulcatus larvae.

Results: A single larva of $A$. sulcatus consumed on an average 34 IV instar larvae of $C x$. quinquefasciatus in a $24 \mathrm{~h}$ period. It was observed that feeding rate of $A$. sulcatus did not differ between the light-on ( 6 a.m. -6 p.m.), and dark (6 p.m. -6 a.m.) phases, but decreased with the volume of water i.e., space availability. The prey consumption of the larvae of $A$. sulcatus differed significantly $(P<0.05)$ with different prey, predator and volume combinations, revealed through univariate ANOVA. The field study revealed a significant decrease $(p<0.05)$ in larval density of different species of mosquitoes after 30 days from the introduction of $A$. sulcatus larvae, while with the withdrawal, a significant increase $(p<0.05)$ in larval density was noted indicating the efficacy of A. sulcatus in regulating mosquito immatures. In the control tanks, mean larval density did not differ $(p>0.05)$ throughout the study period.

Conclusion: the larvae of the dytiscid beetle $A$. sulcatus proved to be an efficient predator of mosquito immatures and may be useful in biocontrol of medically important mosquitoes. 


\section{Background}

The chemical methods to regulate mosquito populations bear adverse impacts of resistant strains and effects on the non-target species $[1,2]$. As a sustainable alternative, increasing attention is being paid to control mosquitoes by biological means, including the utilization of natural predators of mosquito immatures [3,4]. Many of these predators, like the larvivorous fishes [5], crustaceans Triops newberryii [6] and Mesoccyclops thermocyclopoides [7], the belostomatid bugs Diplonychus (= Sphaerodema) annulatus, D. rusticus [8-11], notonectid bugs Notonecta maculata [12]Enithares indica [13], Anisops bouvieri $[14,15]$ and the odonates like Enallagma civile [16], Anax imperator [17], Brachytron pratense [18] and some other species [1923] have shown potential in regulating mosquito immatures. Even, the predatory larvae of the mosquitoes Toxorhynchites rutilus [24] and Tx. splendens [25] have been efficient in regulating vector and pest mosquito populations, both under field and laboratory conditions [26]. In smaller annual habitats like containers and tree holes, the copepods, especially, Mesocyclops thermocyclopoides $[7,27]$, can be effective in regulating population of mosquito immatures.

Of the several predators stated above, coleopteran larvae are one such group that has been explored less compared to other similar controphic insects. The dytiscid beetles like Rhantus sikkimensis [28], R. consputus [29] and Colymbates paykulli, Hydroporus sp, and Ilybus ater [30] are known to prey upon mosquito immatures. In ricefields and temporary pools, larvae and adults of dytiscid beetles are dominant predators and have a strong impact in regulating tadpoles and different insect groups [31-34]. Considering the predatory nature of the dytiscid beetles, an assessment of the larvae of Acilius sulcatus Linnaeus 1758 (Coleoptera: Dytiscidae) was made as bio-control agent against the filarial vector Culex quinquefasciatus Say 1823, both under laboratory and field conditions. The dytiscid beetles $A$. sulcatus are common to abundant in the ricefield and temporary pool and bogs of West Bengal, India. Since these habitats are also exploited by mosquitoes fro breeding, the results of the present study will highlight their use in such situations as biocontrol agents.

\section{Methods}

\section{Laboratory experiment}

The IV instar larvae of A. sulcatus (Order: Coleoptera) were collected from shallow ponds and rice fields and Larvae of Cx. quinquefasciatus from drains of Burdwan, West Bengal, India and colony was maintained in the Mosquito Research Unit of the Department of Zoology, Burdwan University. Average length of $A$. sulcatus larvae taken for study was $1.7 \mathrm{~cm}( \pm 0.12 \mathrm{SE} ; \mathrm{n}=10)$. One and five $A$. sulcatus were provided with 200 and 1000 newly emerged IV instar $C x$. quinquefasciatus larvae as prey for a period of 24 $\mathrm{hr}$ in glass jars $(20 \mathrm{~cm} \times 15 \mathrm{~cm} \times 25 \mathrm{~cm} ; 5 \mathrm{~L}$ capacity $)$ containing $1 \mathrm{~L}$ and $5 \mathrm{~L}$ of pond water respectively. The pond water of the habitat of A. sulcatus, was used in the experiments after sieving through a net (>500 mesh) to exclude any larvae of other predator species. The water temperature ranged from 23.8 to $27^{\circ} \mathrm{C}$, $\mathrm{pH}$ from 6.67 to 6.84 and dissolved oxygen from 5.33 to $6.23 \mathrm{mg} / \mathrm{l}$, during the experiment. Abrupt changes in the quality of holding water during rearing and experimentation were avoided. The predation experiment was conducted three times on three separate days, each with three replications. A control experiment was done every time. The number of $C x$. quinquefasciatus larvae consumed by A. sulcatus larva during lights-on (0600 - $1800 \mathrm{~h}$, IST-Indian Standard Time) and lights-off phase (1800 - $0600 \mathrm{~h}$, IST) was noted through one day at an interval of $3 \mathrm{hrs}$. After counting the number of consumed larvae, after every $3 \mathrm{hr}$, the same numbers of larvae were replenished within the glass jars to maintain the same prey density. The experiment was commenced at $6 \mathrm{a} . \mathrm{m}$. of a day and those were completed at $6 \mathrm{a}$.m. of the next day to observe the daily feeding rate. The length of the lights-on and lights-off phases were maintained by the application of artificial lights (Tube fluorescent lights), set on the walls of the laboratory $(6 \times 40 \mathrm{Watt})$. The lights-on phase in the laboratory synchronized manually with the natural outdoor sunlight photo phase and the lights-off phase with the dark phase of the night.

To evaluate the predation of the larval forms of A. sulcatus on the 4th instar larvae of $C x$. quinquefasciatus, different combinations of prey, predator and volume of water were considered. In each case nine replicate for one combination were made. The combinations were as stated below:

a) 1 predator, 1 litre of water, 200 numbers of prey - combination $\mathrm{A}$

b) 1 predator, 2 litres of water, 200 numbers of prey combination $\mathrm{B}$

c) 1 predator, 1 litre of water and 400 numbers of prey combination $\mathrm{C}$

d) 2 predators, 1 litre of water and 200 numbers of prey combination D

e) 2 predators, 2 litre of water and 200 numbers of prey combination $\mathrm{E}$

f) 2 predators, 1 litre of water and 400 numbers of prey combination $\mathrm{F}$

The rate of predation for a period of $24 \mathrm{~h}$ was noted and the data was used to calculate the clearance rate $(\mathrm{CR}=$ number of prey/h/predator) an indicator of predatory effi- 
ciency. The CR values were obtained applying the following formula, following Gilbert and Burns [35], with certain modifications;

$$
\mathrm{CR}=\mathrm{V} \cdot(\ln \mathrm{P}) / \mathrm{T} \cdot \mathrm{N}
$$

Where, $\mathrm{V}=$ volume of water (in litre), $\ln =$ Natural $\log , \mathrm{P}$ = number of prey killed/consumed, $\mathrm{T}=$ time, i.e. 24 h., $\mathrm{N}$ $=$ number of predator.

\section{Field experiment}

To examine the efficacy of larvae of A. sulcatus in field condition, Sainthia in the district of Birbhum, West Bengal, India was selected. In the study area, ten cemented tanks (which were located in open air and contained about 250 L of water) were selected. These tanks are usually used in processing of paddy. The tanks remain unused for a long time i.e. from post rainy season to early spring (Sep to Feb), and played the role as natural breeding places of mosquitoes. The tanks were made free from any larvae or nymphs of larvivorous insects or fishes by a fine net having mesh size of $>130$, which allowed the passage of mosquito larvae. Those tanks contained mosquito larvae of different species namely Cx. quinquefasciatus (Say,1823), Cx. bitaeniorhynchus (Giles,1901), Cx. tritaeniorhynchus (Giles, 1901), Cx. vishnui (Theobald, 1901), Cx. gelidus (Theobald,1901), An. subpictus (Grassi, 1889), An. vagus (Doenitz, 1902), An. aconitus (Doenitz,1902), An. barbirostris (Van der Wulp, 1884), An. annularis (Van der Wulp, 1884) and Armigeres subalbatus (Coquillett,1898). Each time 5 dips were taken in each tank and the mean per dip (250 ml dipper) larval density of each of those 10 tanks was assessed according to WHO, 1975 [36] for 15 times at an interval of 90 minutes on a specific day (total $5 \times 15$ dips in each tank). Then twenty larvae of A. sulcatus were introduced in each of first five tanks (No. 1 to 5 ). Five tanks no. 6 to 10 were kept as control to rule out the possibility of decreasing prey density by the activity of Zooplanktons like copepods. Larval densities in those tanks were assessed 30 days after introduction of Acilius larvae for 15 times in similar manner and on the next day all the predator larvae were removed. Densities were assessed again after 30 days from the withdrawal of $A$. sulcatus larvae from the tanks. The experiments (both in laboratory and in the field) were conducted in the months of June, July and August 2007. Re-colonization of tanks by larvae of other larvivorous insects was controlled by netting (>130 mesh) the tanks at an interval of 15 days during the study period. Methods of Ghosh et al. [37-39] and Chatterjee et al. [18] were used to conduct laboratory and field experiments during the present study.

The data obtained on clearance rate for each combination was subjected to one-way ANOVA followed by Tukey's post hoc test [40] to justify the differences, if any, between the combinations. Besides, Students' t-tests and ' $\mathrm{Z}$ ' tests [40] were performed to evaluate the difference in mosquito larval density in the field conditions before and after the presence of the A. sulcatus larvae in the mesocosms.

\section{Results \\ Laboratory experiment}

The larva of $A$. sulcatus was observed to capture the mosquito larva prey on its head, sucked its body fluid as a part of extra oral digestion [34] and discarded some portions of the prey body within a few minutes. The feeding of the larval dytiscid beetles involves mandibles for capturing prey and transfer of enzymes into the tissues and accumulating partially digested pieces of the tissue [34]. The feeding posture of an A. sulcatus larva on a Culex larva has been presented in Plate [see Additional file 1]. Three hourly consumption rates of one and five A. sulcatus larvae on 200 and $10004^{\text {th }}$ instar $C x$. quinquefasciatus larvae respectively have been presented in Fig 1. One A. sulcatus larva consumed 18 and 16 mosquito larvae during light on and light off phases respectively with a daily feeding rate of 34 larvae on an average. Five A. sulcatus larvae consumed 166 mosquito larvae during light on phase and 172 larvae during light off phase with a an average feeding rate of 33.8 larvae/predator in a $24 \mathrm{~h}$ period. The number of prey killed varied with the density of preys and predators available in a particular volume of water (Fig. 2). The clearance rate value ranged between 13.59 and 20.09 no. of prey L/ $\mathrm{h} /$ predator. The maximum CR value was obtained when the predator larva was present in larger space (Fig. 3.). One way ANOVA revealed significant differences in the clearance rate at different combinations (Table 1 ). The result of the post hoc Tukey's test is presented in Fig 3. The results are suggestive of the fact that the larval stages of $A$. sulcatus exhibited varied predatory efficiency depending on the availability of space and the number of predators.

\section{Field experiment}

Variations in the density of mosquito larval population with the introduction and removal of A. sulcatus larvae in the field are presented in Fig 4 which revealed that average per dip density of mosquito larvae reduced from 23.03 to 13.28 after 30 days from the introduction of $A$. sulcatus larvae in treated vats i.e., from vat no. 1 to 5 where the difference was significant $\left(\mathrm{t}_{(0.05,14)}=16.00 ; \mathrm{p}<0.05\right)$. Again larval density increased significantly $\left(\mathrm{t}_{(0.05,14)}=17.35 ; \mathrm{p}<\right.$ 0.05 ) from 13.28 to 20.97 in those vats (no. 1 to 5 ) after 30 days from the removal of predator species. Control vats (No. 6 to 10$)$ did not show any difference $\left(t_{(0.05,14)}=1.53\right.$ $\left.; \mathrm{t}_{(0.05,14)}=1.35 ; \mathrm{p}>0.05\right)$ in average larval densities $(23.00,22.79$ and 22.57$)$ throughout the study period [Table value of ' $\mathrm{t}$ ' $=2.145]$. 


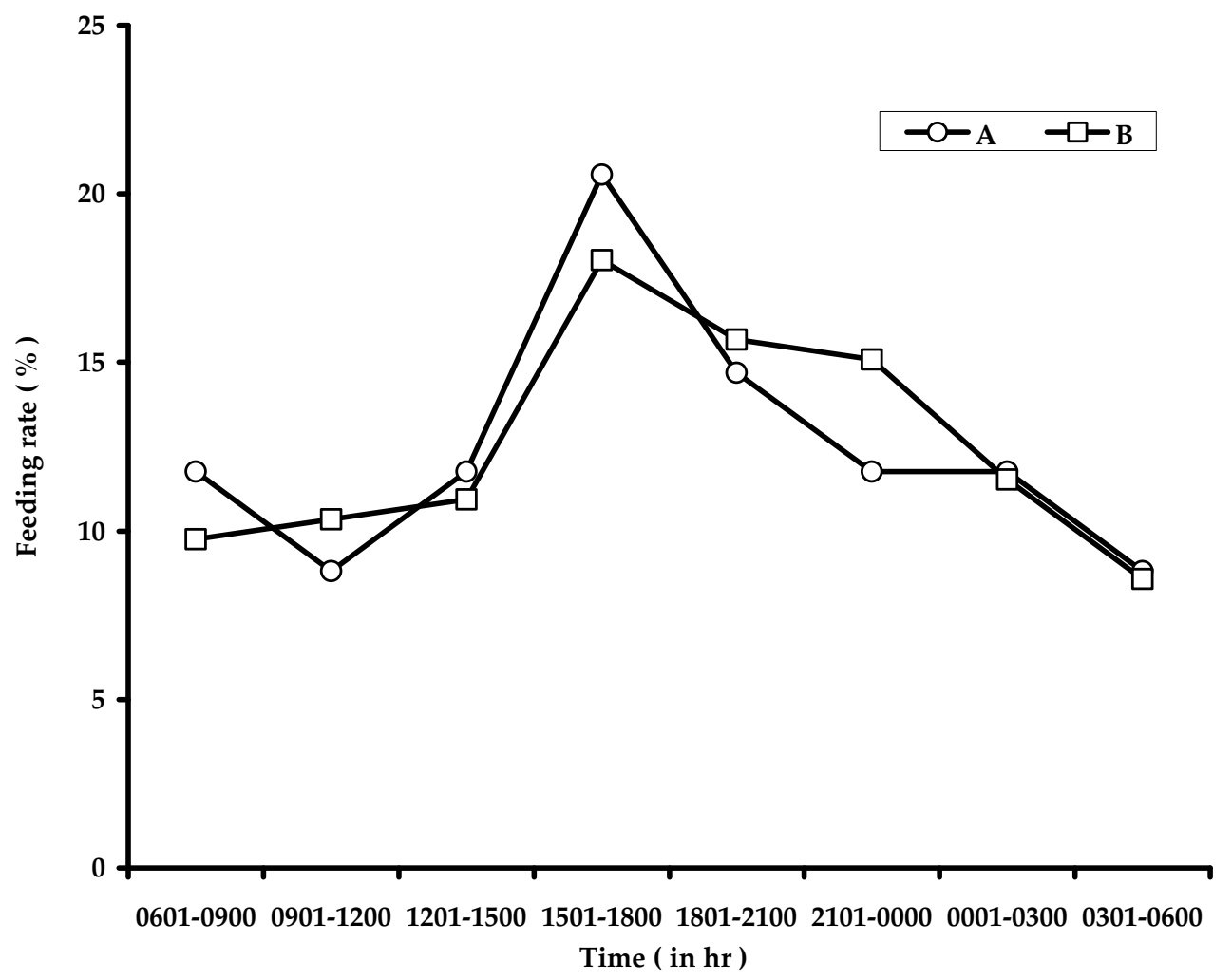

Figure I

Three-hourly feeding rate of larvae of A. sulcatus on IV instar larvae of Cx. quinquefasciatus. A: 200 preys: I predator; B: 1000 preys: 5 predators.

No predator mortality was recorded during the study period i.e. all 20 larvae of A. sulcatus introduced in each tank were actually recovered.

\section{Discussion}

Present study revealed that $A$. sulcatus larva was active feeder and remained active throughout day and night, though it consumed apparently greater $[Z=1.233$ (Table value $=1.56) ; \mathrm{p}>0.05]$ number of mosquito larvae during light on phase in comparison to light off phase. In recent years, predation and population regulation of Culex larvae by the dytiscid beetles Rhantus sikkimensis in India [28]Hydroporus sp, Colymbetes paykulli and Ilybus ater in Sweden [30]. However, under presence of alternative preys the selection for mosquito by these dytiscid beetles was less prominent compared to R. consputus [29]. In comparison to these beetles, the prey consumption of the larva of A. sulcatus was found to be higher. Further, under field conditions, the reduction in the populations of mosquito immatures in presence of the larvae of $A$. sulcatus indicates its efficiency as biocontrol agent. The efficacy of $A$. sulcatus was noted to be as good as larvivorous fishes like Xenento- don cancila fry, Gambusia affinis and Poecilia reticulata [4143].

In the field larval densities reduced gradually after introduction of predator larvae in the mosquito breeding places and a significant difference in larval density was noted after one month from the introduction. On the other hand, larval densities increased gradually after removal of predator larvae from the treated breeding spots and a significant difference in larval density was noted after one month from their removal. Insignificant difference in larval density in the control tanks during the period of field experiment excluded the possibility of influence/effect of other factors and confirmed the role of predator in decreasing the larval density of mosquito in treated tanks. Considering the natural habitats of A. sulcatus and other aquatic coleopteran insects, the effects of alternative prey on the prey selection and predation ecology need to be evaluated prior to promoting these beetles for biological control. Like the dytiscid beetles $R$. consputus and the copepods $M$. thermocyclopoides positive selection for the mosquito larvae by A. sulcatus need to be evalu- 


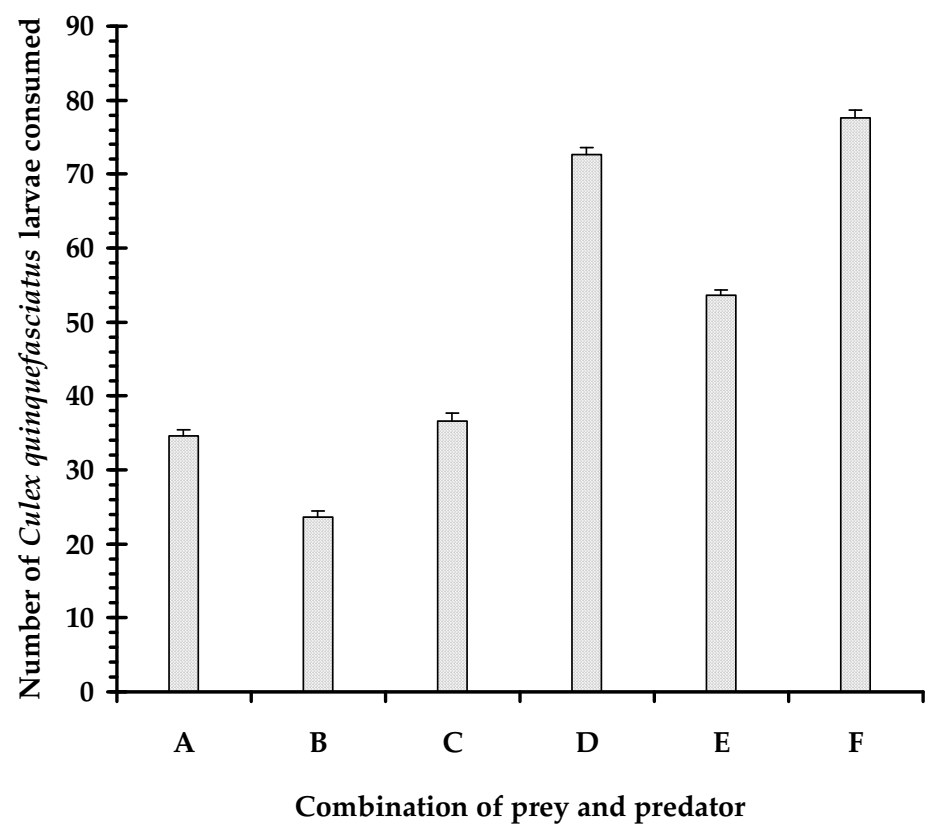

Figure 2

The number of prey consumed by a larva of $A$. sulcatus under different combinations (A - F) of prey, predator and volume of water.

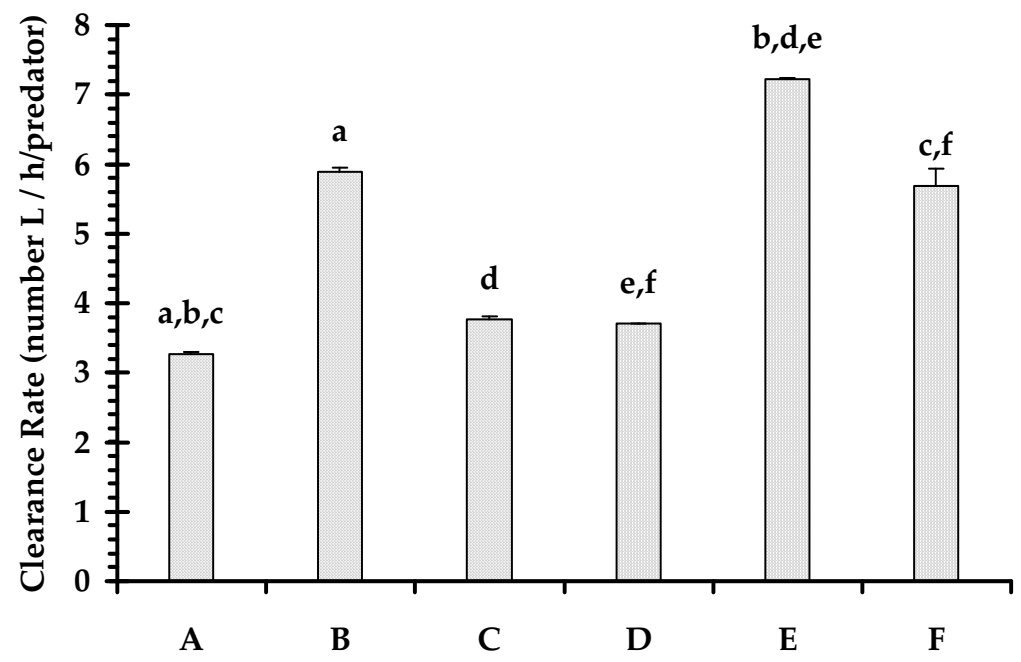

Combinations of prey and predators

Figure 3

The clearance rate of the larvae of $A$. sulcatus under different combinations (A - F) of prey, predator and water volume ( $\mathbf{n}=\mathbf{9}$ trials/combinations). The letters shared by the bars represents significant differences between the combinations at $\mathrm{P}<0.01$, revealed through post hoc Tukey test. 
Table I: Results of ANOVA on the clearance rate of $A$. sulcatus on IV instar $C_{x}$. quinquefasciatus larvae, under different combinations

\begin{tabular}{lcccc}
\hline Source of variation & SS & df & MS & F-value \\
\hline $\begin{array}{l}\text { Between combinations } \\
\text { Residual }\end{array}$ & 4.68 & 5 & 0.94 & $9.14(\mathrm{P}<0.00 \mathrm{I})$ \\
\hline Total & 4.92 & 48 & 0.1 & \\
\hline
\end{tabular}

ated. Nonetheless, in conditions of coexistence of multiple species of mosquitoes the larvae of $A$. sulcatus consumed the mosquito immatures without discrimination of a particular species. This is relevant in field conditions where multiple species of mosquitoes will be present.

\section{Conclusion}

The A. sulcatus larva has been effective as predator of mosquito immatures and may be useful in biocontrol of medically important mosquitoes. From the viewpoint of efficient and sustainable biological control in the field condition, the aquatic predators should have a wide range of adaptability in the habitats apart from the predation of target mosquito larvae. Further work is necessary to determine the proper methodology of mass rearing and augmentative release of Acilius larva to make this biocontrol procedure possible for wide application.

\section{Competing interests}

The authors declare that they have no competing interests.

\section{Authors' contributions}

GC designed the study, supervised the experiments and wrote the manuscript in most parts. SKM performed the laboratory experiments. AKG, DD and SB performed the

\footnotetext{
$\checkmark$ Before introduction of predator larvae (day 0 )
}

-30 days after introduction of predator larvae (day 30)

... $*$... Control vat (day 0 )

..... Control vat (day 60 )

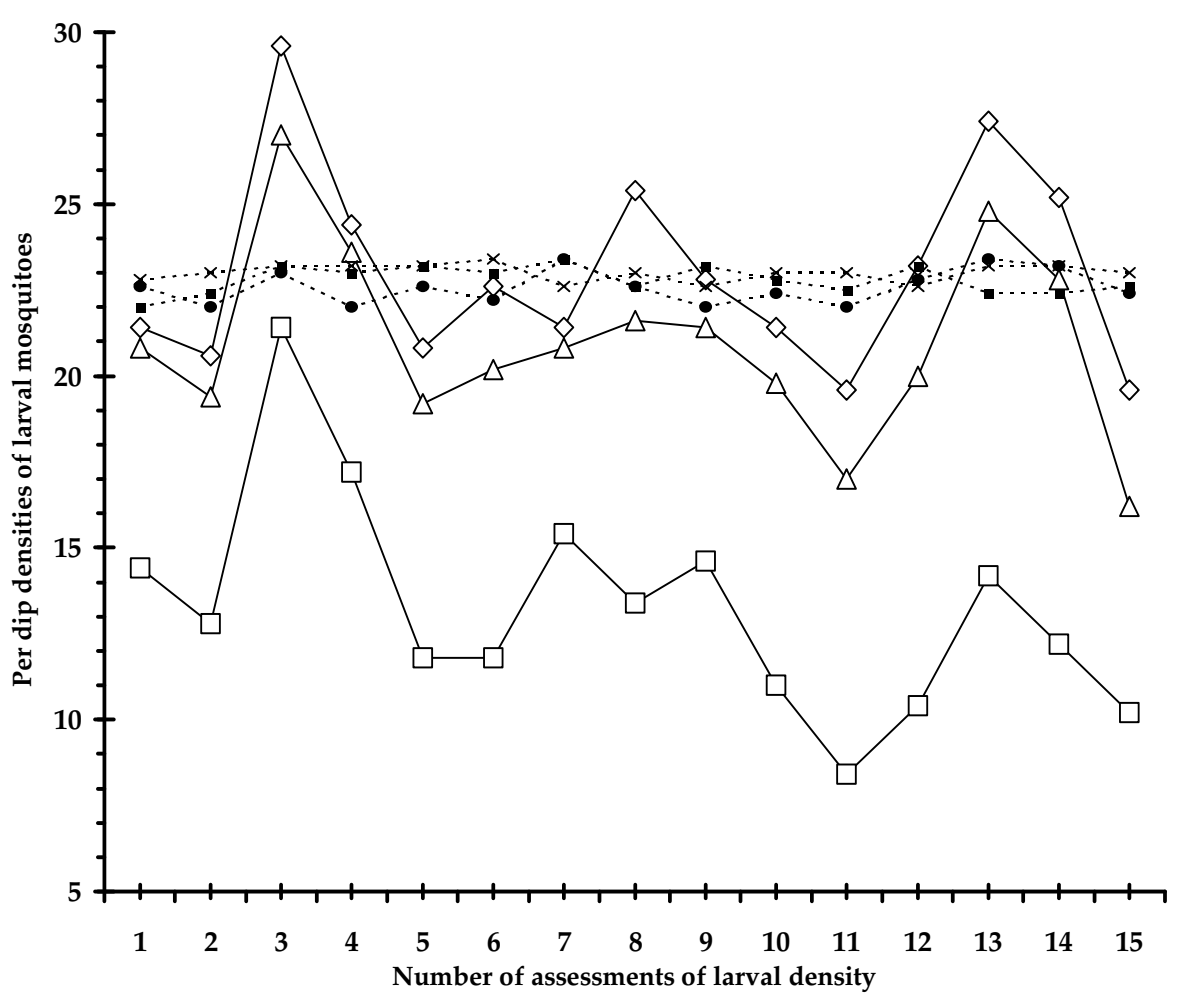

\section{Figure 4}

Efficacy of $A$. sulcatus larva as biocontrol agent against larval form of different mosquitoes in the field conditions. 
field experiments and data analysis. SC did statistical analysis and photography.

\section{Additional material}

\section{Additional File 1}

Feeding posture of A. sulcatus on $\mathrm{Cx}$. quinquefasciatus larvae. Prey (Cx. quinquefasciatus) capture by the larva of A. sulcatus. Click here for file

[http://www.biomedcentral.com/content/supplementary/14712334-8-138-S1.doc]

\section{Acknowledgements}

Laboratory facilities provided by the Burdwan University Authority are thankfully acknowledged.

\section{References}

I. WHO: Manual on practical entomology in malaria part II (Methods and Terminology) Geneva 1975:78.

2. Karunaratne $\mathrm{SH}$, Hemingway J: Insecticide resistance spectra and resistance mechanisms in populations of Japanese encephalitis vector mosquitoes, Culex tritaeniorhynchus and Cx. gelidus, in Sri Lanka. Med Vet Entomol 2000, 14:430-436.

3. Kumar R, Hwang JS: Larvicidal efficiency of aquatic predators: A perspective for mosquito biocontrol. Zool Stud 2006, 45(4):447-466.

4. Voyadjoglou AS, Roussis V, Petrakis PV: Biological control of mosquito populations: An applied aspect of pest control by means of natural enemies. In Predation in Organisms: A distinct phenomenon Edited by: Elewa AMT. Springer: Berlin; 2007:I23-|49.

5. Chandra G, Bhattacharjee I, Ghosh A, Chatterjee SN: Mosquito control by larvivorous fishes. Indian I Med Res 2008, 127:13-27.

6. Su T, Mulla MS: Introduction and establishment of tadpole shrimp Triops newberryi (Notostraca:Triopsidae) in a date garden for biological control of mosquitoes in Coachella Valley, southern California. J Vector Ecol 2002, 27( I): | 38-| 48.

7. Kumar R, Rao TR: Predation on mosquito larvae by Mesocyclops thermocyclopoides (Copepoda: Cyclopoida) in presence of alternate prey. Int Rev Hydrobiol 2003, 88:570-58I.

8. Aditya G, Bhattacharyya S, Kundu N, Saha GK, Raut SK: Predatory efficiency of the water bug Sphaerodema annulatum on mosquito larvae (Culex quinquefasciatus) and its effect on adult emergence. Bioresource Technology 2004, 95:169-172.

9. Aditya G, Bhattacharyya S, Kundu N, Saha GK: Frequency-dependent prey selection of predacious water bugs on Armigeres subalbatus immatures. J Vector Borne Dis 2005, 42(I):9-|4.

10. Pramanik MK, Raut SK: Water-bug Sphaerodema rusticum Fabricius destroying vector mosquitoes larvae. J Natl Taiwan Mus 2003, 56:9-24.

II. Pramanik MK, Raut SK: Predation rhythm of the water bug Sphaerodema rusticum Fabricius. Environ Ecol 2005, 23(3):707-7I3.

12. Blaustein L: Influence of the predatory backswimmer, Notonecta maculata, on invertebrate community structure. Ecol Entomol 1998, 23:246-252.

13. Wattal S, Adak T, Dhiman RC, Sharma VP: The biology and predatory potential of the notonectid bug, Enithares indica (Fabr) against mosquito larvae. Southeast Asian J Trop Med Public Health 1996, 27(3):633-636.

14. Saha N, Aditya G, Bal A, Saha GK: A comparative study of predation of three aquatic Heteropteran bugs on Culex quinquefasciatus larvae. Limnology 2007, 8(I):73-80.

15. Saha N, Aditya G, Bal A, Saha GK: Comparative studies on functional response of common heteropteran bugs of East Calcutta Wetlands, Kolkata, India. Int Rev Hydrobiol 2007, 92(3):242-257.
16. Miura T, Takahashi R: A laboratory study of predation of damselfly nymphs, Enallagma civile, upon mosquito larvae, Culex tarsalis. J Am Mosq Control Assoc 1988, 4(2): I29-I31.

17. Stav G, Blaustein L, Margalit Y: Individual and interactive effects of a predator and controphic species on mosquito populations. Ecol Appl 2005, I 5(2):587-598.

18. Chatterjee SN, Ghosh A, Chandra G: Eco-friendly control of mosquito larvae by Brachytron pratense nymph. J Environ Health 2007, 69(8):44-48.

19. Mathavan S: Satiation time and predatory behaviour of the dragonfly nymphs Mesogomphus lineatus. Hydrobiologia 1976, 50:55-64.

20. Yanoviak SP: Predation, resource availability, and community structure in Neotropical water filled tree holes. Oecologia (Berl) 200I, I 26: 125-133.

21. Sebastian A, Sein MM, Thu MM, Corbet PS: Suppression of Aedes aegypti (Diptera: Culicidae) using augmentative release of dragonfly larvae (Odonata: Libellulidae) with community participation in Yangon, Myanmar. Bull Entomol Res 1990, 80:223-232

22. Corbet PS: Use of odonate larvae for biocontrol of insect pests. Agrion 2000, 4/2:22-27.

23. Fincke OM: Organization of predator assemblages in Neotropical tree holes: effects of abiotic factors and priority. Ecol Entomol 1999, 24:13-23.

24. Lounibos LP, Escher RL, Nishimura N, Juliano SA: Long-term dynamics of a predator used for biological control and decoupling from mosquito prey in a subtropical tree hole ecosystem. Oecologia (Berl) 1997, I I I: | 89-200.

25. Pramanik MK, Raut SK: Occurrence of the giant mosquito Toxorhynchites splendens in drains and its predation potential on some vector mosquitoes of Kolkata (Calcutta), India. J Med Entomol Zool (Japan) 2003, 54(4):315-323

26. Collins LE, Blackwell A: the biology of toxorhynchites mosquitoes and their potential as biocontrol agents. Biocontr News Info 2000: 105N-I I6N.

27. Mittal PK, Dhiman RC, Adak T, Sharma VP: Laboratory evaluation of the biocontrol potential of Mesocyclops thermocyclopoides (Copepoda: Cyclopidae) against mosquito larvae. Southeast Asian J Trop Med Public Health 1997, 28(4):857-86I.

28. Aditya G, Saha GK: Predation of the beetle Rhantus sikkimensis (Coleoptera: Dytiscidae) on the larvae of Chironomus Meigen (Diptera: Chironomidae) of the Darjeeling Himalayas of India. Limnologica 2006, 36(4):25 I-257.

29. von Kögel F: Zur biologie und ökologie von Rhantus consputus STRM. Entomol Arb Mus 1987, 35/36:5-19.

30. Lundkvist E, Landin J, Jackson M, Svensson C: Diving beetles (Dytiscidae) as predators of mosquito larvae (Culicidae) in field experiments and in laboratory tests of prey preference. Bull Entomol Res 2003, 93:219-226.

31. Batzer DP, Resh VH: Trophic Interactions among a Beetle Predator, a Chironomid Grazer, and Periphyton in a Seasonal Wetland. Oikos |99|, 60(2):25I-257.

32. Heiss JS, Harp GL, Meisch MV: Aquatic Coleoptera Associated with Arkansas Rice, with Observations on the Effects of Carbofuran, Molinate, Predatory Fish and Late-Planting. Southwest Nat 1986, 3 I (4):52I-525.

33. Formanowicz DR Jr, Bobka MS: Predation risk and microhabitat preference: an experimental study of behavioural respeonse of prey and predator. Am Mid Nat 1989, I 2 I:379-386.

34. Wall WP, Barman EH, Beals CM: A description and functional interpretation of the mandibular geometry of Agabus punctatus Melsheimer, Rhantus calidus (Fabricius, I 792) and Acilius mediatus (Say, I 823), (Coleoptera: Dytiscidae). Aquatic Insects 1844, 28(4):277-289.

35. Gilbert JJ, Burns CW: Some observations on the diet of the back swimmer, Anisops wakefieldi Hemiptera: Notonectidae). Hydrobiology 1999, 412: III-II8.

36. WHO: Manual on practical entomology in malaria part II (Methods and Terminology) Geneva 1975:78.

37. Ghosh A, Bhattacharjee I, Ganguly M, Mondal S, Chandra G: Efficacy of some common aquarium fishes as biocontrol agent of preadult mosquitoes. Bull Pen Kesh 2004, 32(4): | 44- I49.

38. Ghosh A, Mondal S, Bhattacharjee I, Chandra G: Biological control of vector mosquitoes by some common exotic fish predators. Turk J Biol 2005, 29:|67-I7|. 
39. Ghosh A, Bhattacharjee I, Chandra G: Biocontrol efficacy of Oreochromis nilotica nilotica. against larval mosquitoes. J Appl Zool Res 2006, 17(1): II4-II6.

40. Zar JH: Biostatistical analysis IV edition. Singapore : Pearson Education (Singapore) (P) Ltd., New Delhi (Indian Branch); 1999:I-663.

41. Chandra G, Chatterjee SN: Laboratory trials on feeding pattern of Anopheles subpictus, Culex quinquefasciatus and Armigeres subalbatus larvae by Xenentodon cancila fry. Environ Ecol 1996, 14:173-174.

42. Chatterjee SN, Chandra G: Laboratory trails on the feeding pattern of Anopheles subpictus, Culex quinquefasciatus and Armigeres subalbatus larvae by Gambusia affinis. Sci Cult 1997, 63:5I-52.

43. Chatterjee SN, Chandra G: Feeding pattern of Gambusia affinis and Lebistes reticulatus on Anopheles subpictus larvae in the laboratory and field conditions. J Appl Zool Res 1997, 8(2): $152-153$.

\section{Pre-publication history}

The pre-publication history for this paper can be accessed here:

http://www.biomedcentral.com/1471-2334/8/138/pre pub
Publish with Biomed Central and every scientist can read your work free of charge

"BioMed Central will be the most significant development for disseminating the results of biomedical research in our lifetime. "

Sir Paul Nurse, Cancer Research UK

Your research papers will be:

- available free of charge to the entire biomedical community

- peer reviewed and published immediately upon acceptance

- cited in PubMed and archived on PubMed Central

- yours - you keep the copyright

Submit your manuscript here:

http://www.biomedcentral.com/info/publishing_adv.asp 